\title{
Experimental Study of Thermoelectric Generator as Electrical Source of Impressed Current Cathodic Protection for Ship Hull
}

\author{
Adi Kurniawan ${ }^{1}$, Sutopo Purwono Fitri ${ }^{2}$, Muhammad Fajrul Rahman ${ }^{3}$
}

\begin{abstract}
ICCP) is a method to protect metallic material such as ship hull from corrosion by using electric current. In this research, a prototype of thermoelectric generator is developed in order to supply the ICCP system. This thermoelectric generator is planned to utilize the exhaust gas from main engine of the ship. Method carried in this research is assembling the prototype of thermoelectric generator followed by conducted experiment to observe the potential energy of the prototype. After that, the required number of thermoelectric generator is calculated to supply the ICCP system to protect the ship from corrosion. The object in this research is live fish carrier "Wellboat" which has $396.08 \mathrm{~m}^{2}$ wetted area. The required voltage and current to protect the ship from corrosion for three years are 16.67 Volt and 2.66 Ampere. Based on the experiment, a prototype of thermoelectric generator can generate 0.34 Ampere and 4.43 Volt, causing the need of 8 series and 4 parallels connection. It can be concluded that the corrosion rate on the ship hull can be decelerated by using impressed current cathodic protection method without needing additional cost or fuel consumption to produce electric energy.
\end{abstract}

Keywords—alternative energy, corrosion, main engine exhaust gas, metal protection

\section{INTRODUCTION}

$\mathrm{C}$ orrosion is one issue that has to be considered in ship maintenance field. The quality of metal on the hull is degrading by the time since the electron of the metal is released to the sea. Without corrosion protection, the hull needs to be replaced frequently.

One of the methods which able to protect the ship hull from corrosion is cathodic protection, which is done by connecting hull into anodic metal. The rate of corrosion can be slowed since the hull receive electron from the anode. There are two types of cathodic protection. The first is sacrificial anode cathodic protection (SACP). In SACP, the anodic metal acts as the electron supplier for cathode. This method is not economical because the anodic metal has to be replaced each time the metal run out [1]. The second cathodic protection method is impressed current cathodic protection (ICCP). Unlike SACP, the anode in ICCP is not run out fast because it receive electron from electric supply [2].

The electric supply for ICCP system can be from any electrical source such as main generator, battery or even renewable energy source. As the cost of generator fuel oil and battery is expensive, the use of renewable or sustainable waste energy for the ship application such as solar energy [3-8] or even sound in engine room [9] is preferred. One example of ICCP with renewable energy source is in [10] which utilizing voltaic cell with sea water as the electrolyte.

Adi Kurniawan is with Departement of Marine Engineering, Institut Teknologi Sepuluh Nopember, Surabaya, 60111, Indonesia.

E-mail:adi.kurniawan@ne.its.ac.id

Sutopo Purwono Fitri is with Departement of Marine Engineering, Institut Teknologi Sepuluh Nopember, Surabaya, 60111, Indonesia E-mail:sutopopf@.its.ac.id

Muhammad Fajrul Rahman is student of Departement of Marine Engineering, Institut Teknologi Sepuluh Nopember, Surabaya, 60111, Indonesia. E-mail:fajrul@engineer.com
In this research, a sustainable waste energy-based electric source is proposed in the form of thermoelectric generator. Thermoelectric generator is a device which able to convert the difference of temperature into electrical energy [11]. The thermoelectric generator is planned to utilize the difference temperature between exhaust gas of main engine and natural temperature in engine room. Since the main engine will always be operated when the ship is sailing, the thermoelectric generator will continuously produce the electrical energy. In order to achieve that objective, the prototype of thermoelectric generator has been built and tested in laboratory scale with adjustable temperature difference.

\section{METHOD}

This research is based on experimental study. A prototype of thermoelectric generator is built from thermoelectric element and other supporting element such as heat sink which is used to reduce the heat received by thermoelectric element. After the thermoelectric generator has built, it is tested in laboratory scale to observe its performance.

\section{A. Assembling Thermoelectric Generator}

A prototype of thermoelectric generator is built from four thermoelectric element in which two elements is connected in series and those two series then connected in parallel which is shown in Figure 1. The circuit of thermoelectric elements then attached to a modified heat sink by using thermal paste which is shown in Figure 2. The heat sink is designed with the objective to reduce the heat received by thermoelectric element as much as possible.

\section{B. Experiment Procedure}

Thermoelectric is able to produce electrical energy by utilizing the temperature difference between its upper side and its lower side. In the real ship application, the temperature difference is planned to be obtained from temperature of main engine exhaust gas for the upper 


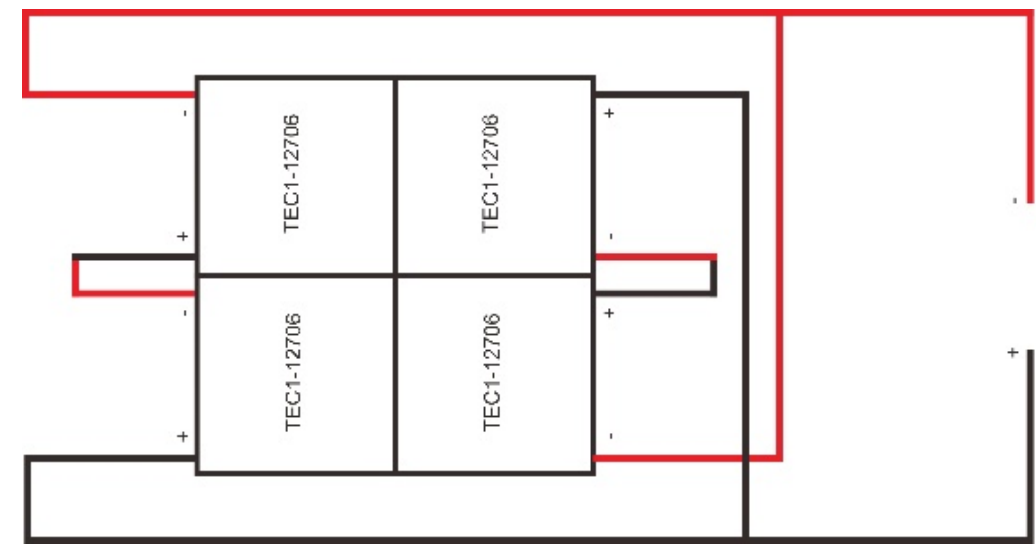

Figure. 1. Circuit of Thermoelectric Generator

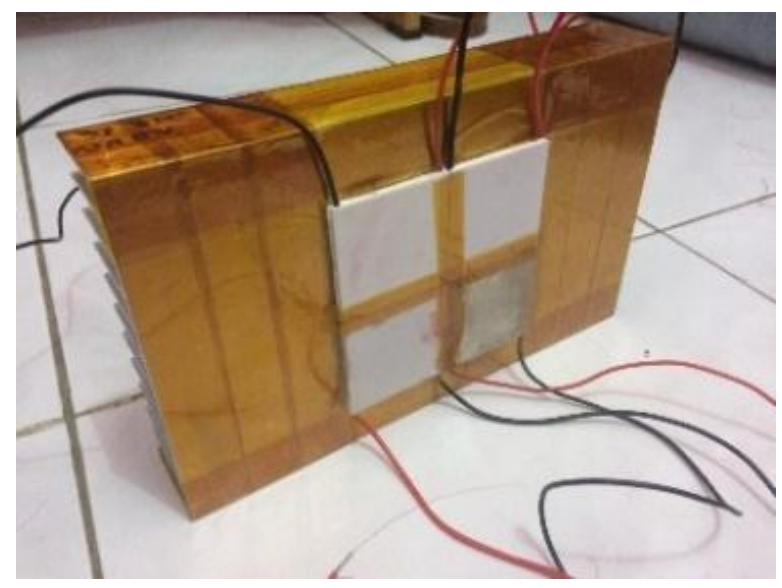

(a)

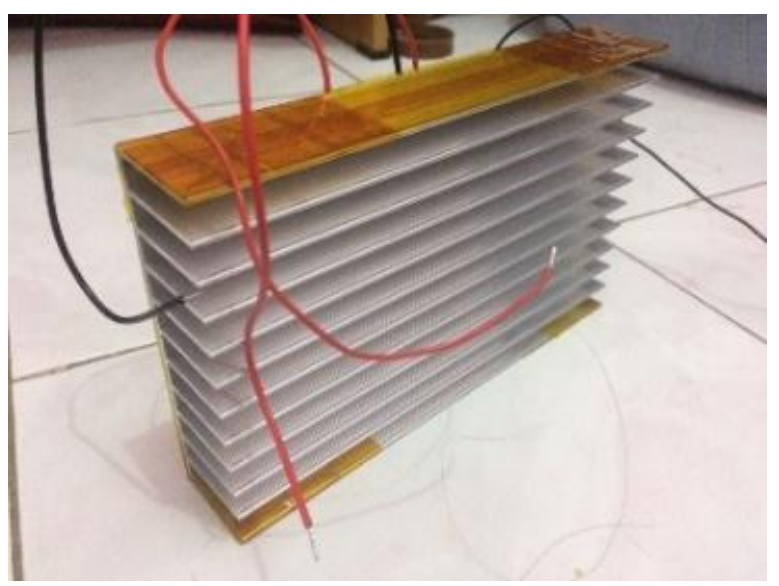

(b)

Figure. 2. The Display of Thermoelectric Generator (a) Front View (b) Rear View

side, and natural engine room temperature for the lower side. The temperature of main engine exhaust gas is around $300{ }^{\circ} \mathrm{C}$ while temperature of engine room is around $40{ }^{\circ} \mathrm{C}$.

In this research, the temperature of exhaust gas is represented using heat gun, while temperature of engine room is represented using natural temperature. The heat gun is pointed to the upper side of thermoelectric element on the thermoelectric generator. The output cable from thermoelectric generator is connected to aluminum anode and small iron hacksaw as cathode which is dipped in the water.

The independent variable in this research is the distance of heat gun to the thermoelectric generator and the debit of air from the heat gun, while the dependent variable is the temperature received by thermoelectric, measured with infrared thermometer, and also output voltage and current of the thermoelectric measured by multi tester. The determined distances between heat gun and thermoelectric generator in this research are 5, 10, 15 and $20 \mathrm{~cm}$. The determined debit of air from the heat gun is 24 and $421 /$ minute. The experimental setup is shown in Figure 3.

\section{Determine Number of Thermoelectric Generator}

Based on the potential energy of thermoelectric generator which is obtained from experiment, the number of thermoelectric generator to supply the ICCP system can be calculated.

The first step to calculate the number of ICCP is determining the total wet surface area of the ship hull which needs to be protected. In this research, this step is done by using Maxsurf software.

The second step is to calculate coating breakdown factor (fc). The value of coating breakdown factor represents the ability of electric current to flow on the coat. If the value of $\mathrm{fc}$ is equal to 0 , it means that no electric current can flow on the coat. The formula to calculate the breakdown coating is written in equation (1).

$f_{c}=(a+b) \times t_{c}$

with:

$\mathrm{f}_{\mathrm{c}}=$ Coating breakdown factor

$\mathrm{t}_{\mathrm{c}}=$ Coating lifetime design $($ year $(\mathrm{s}))$

$\mathrm{a}=1^{\text {st }}$ coating constant

$\mathrm{b}=2^{\text {nd }}$ coating constant

The third step is to calculate the required protection current. The electric source needs to supply certain value of electric current to protect the metal as the lifetime design. The formula to calculate the required protection current is written in equation (2). 


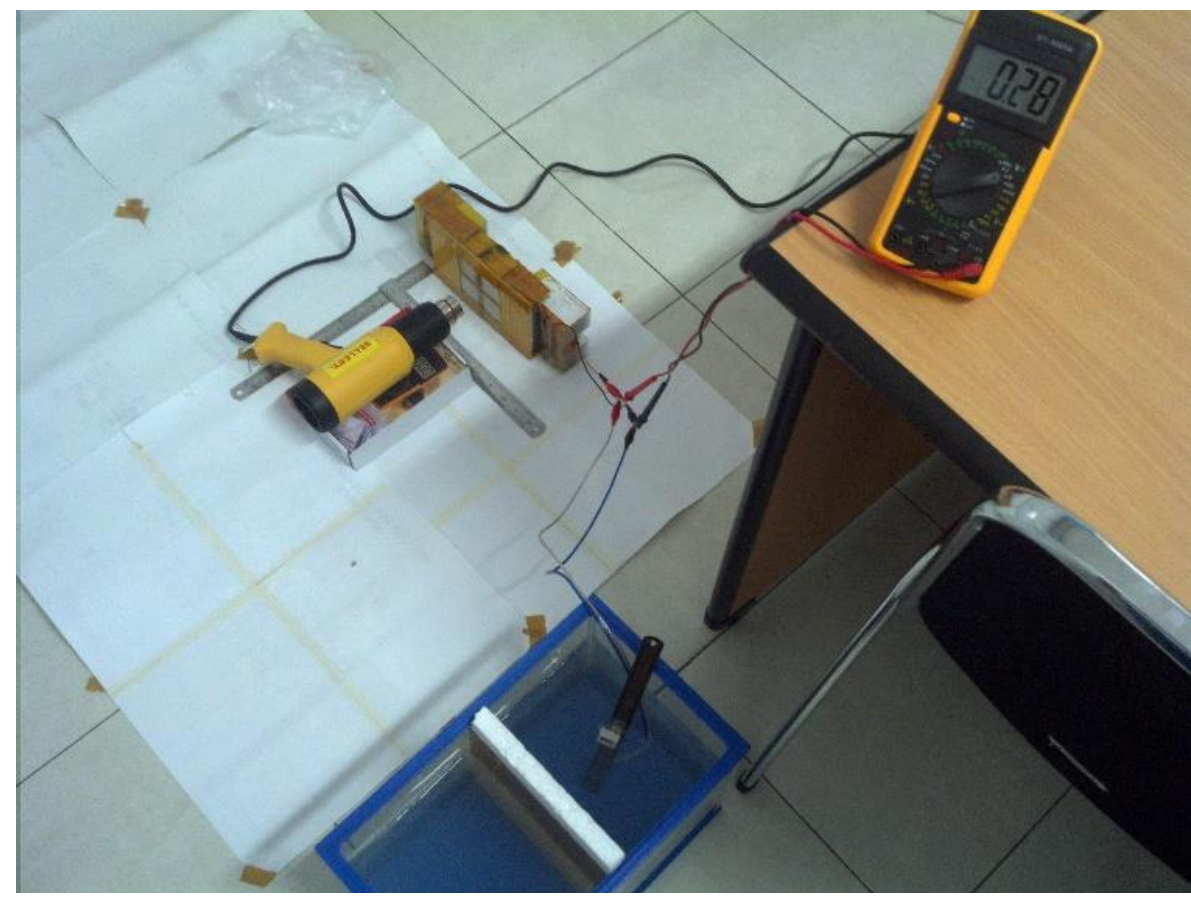

Figure. 3. Experimental Setup of Thermoelectric Generator

$$
I_{c}=A_{c} \times i_{c} \times f_{c}
$$

with:

$\mathrm{I}_{\mathrm{c}}=$ Required protection current (Ampere)

$\mathrm{A}_{\mathrm{c}}=$ Protected area $\left(\mathrm{m}^{2}\right)$

$\mathrm{i}_{\mathrm{c}}=$ Average current density $\left(\mathrm{A} / \mathrm{m}^{2}\right)$

The fourth step is to calculate the mass of anode. The anode used in this system is aluminum W114. The total mass of anode can be calculated using equation (3).

$$
M_{a}=\frac{I_{c} \times t_{c} \times 365 \times 24}{u \times \varepsilon}
$$

with:

$\mathrm{M}_{\mathrm{a}}=$ Total mass of anode $(\mathrm{kg})$

$\mathrm{u}=$ Anode utilizing factor

$\varepsilon=$ Electrochemical efficiency of anode material (A.h/kg)

The fifth step is to calculate the number of required anode. The required number of anode can be calculated using equation (4).

$$
N_{a}=\frac{M_{a}}{M_{1 a}}
$$

with:

$\mathrm{N}_{\mathrm{a}}=$ Number of anode

$\mathrm{M}_{1 \mathrm{a}}=$ Mass of one anode $(\mathrm{kg})$

The sixth step is calculating the anode resistance value in order to determine the required voltage. The formula to calculate anode resistance is written in equation (5).
$R_{a}=\frac{0.315 \times \rho \times N_{a}}{\sqrt{A_{a}}}$

with:

$\mathrm{R}_{\mathrm{a}}=$ Anode resistance (ohm)

$\rho=$ Sea water resistivity (ohm.meter)

$\mathrm{A}_{\mathrm{a}}=$ Anode surface area $\left(\mathrm{m}^{2}\right)$

The seventh step is to calculate the required protection voltage. This value is affected by protection current and anode resistance. The required protection voltage can be calculated using equation (6).

$V_{c}=\left[\left(I_{c} \times R_{a}\right) \times(1+S F)\right]+B_{e m f}$

with:

$\mathrm{V}_{\mathrm{c}}=$ Protection voltage (Volt)

$\mathrm{SF}=$ Safety factor

$\mathrm{B}_{\mathrm{emf}}=\operatorname{Back} \operatorname{EMF}(\mathrm{V})$

The last step is to calculate the number of series and parallel connection of the thermoelectric generator. The number of series connection is depending on the required protection voltage while the number of parallel connection is depending on the required protection current. The formula to calculate the series and parallel connection is written in equation (7) and (8) respectively.

$$
N_{T G s}=\frac{V_{c}}{V_{T G}}
$$

with:

$\mathrm{N}_{\mathrm{TGs}}=$ Number of series connection of thermoelectric 
generator

$\mathrm{V}_{\mathrm{TG}}=$ Voltage of one thermoelectric generator

$$
N_{T G p}=\frac{I_{c}}{I_{T G}}
$$

with:

$\mathrm{N}_{\mathrm{TGp}}=$ Number of parallel connection of thermoelectric generator

$\mathrm{I}_{\mathrm{TG}}=$ Current of one thermoelectric generator

\section{RESULTS AND DISCUSSION}

As mentioned in previous section, the experiment is conducted with two independent variables, which is the distance between heat gun and thermoelectric generator, and also the debit of air from the heat gun. Since there are four values of distance and two values of air debit, there are eight conditions being conducted. Each condition is performed ten times and the mean value of the results is written in Table 1.

The results show that the closer the heat gun to the thermoelectric, and the higher the debit of the heat gun, the temperature difference in thermoelectric generator is getting higher, resulting higher current and voltage. The highest electricity which can be generated by thermoelectric generator is $4.43 \mathrm{~V}$ voltages and $0.34 \mathrm{~A}$ current.

The number of required thermoelectric generator then calculated from the first step, which is determining the wet surface area of the ship hull which needs to be protected. The object of the ship in this research is live fish carrier "Wellboat" which principle dimension is written in Table 2. The shape of the ship is drawn in the Maxsurf software and according to the simulation, this ship has $396.08 \mathrm{~m} 2$ wet surface area which need to be protected from corrosion.

The next step is calculating coating breakdown factor using equation (1). With the coating lifetime design is three years, and $1^{\text {st }}$ coating constant is 0.02 and $2^{\text {nd }}$ coating constant is 0.012 , then the coating breakdown factor is.

$$
\begin{aligned}
& f_{c}=(0.02+0.012) \times 3 \\
& f_{c}=0.096
\end{aligned}
$$

After the protected area and coating breakdown factor has been obtained, the required protection current can be calculated using equation (2) with the target of average current density is $0.07 \mathrm{~A} / \mathrm{m}^{2}$.

$$
\begin{aligned}
& I_{c}=396.08 \times 0.07 \times 0.096 \\
& I_{c}=2.66 \mathrm{~A}
\end{aligned}
$$

The next step is calculating total mass of anode with equation (3). Anode utilizing factor is assumed to be 0.8 and electrochemical efficiency of the anode is 2000 A.h/kg.

$$
\begin{aligned}
& M_{a}=\frac{2.66 \times 3 \times 365 \times 24}{0.8 \times 2000} \\
& M_{a}=43.69 \mathrm{~kg}
\end{aligned}
$$

The total mass of anode then divided with the mass of one anode to get the number of required anode. The anode which will be used is aluminum $\mathrm{W}-114$. The weight of each anode is $9.8 \mathrm{~kg}$. According to equation (4), the number of required anode is calculated below.

$N_{a}=\frac{43.69}{9.8}$

$N_{a}=5$

Based on the number of the anode, the total anode resistance can be calculated using equation (5) with the value of sea water resistivity is $1.3 \mathrm{ohm}$.meter and anode surface area is $0.21 \mathrm{~m}^{2}$

$R_{a}=\frac{0.315 \times 1.3 \times 5}{\sqrt{0.21}}$

$R_{a}=4.47 \mathrm{ohm}$

The required protection voltage then calculated using equation (6), by assuming the safety factor to be 0.2 and back emf to be $2 \mathrm{~V}$.

$V_{c}=[(2.66 \times 4.47) \times(1+0.2)]+2$

$V_{c}=16.27 \mathrm{~V}$

Since the required protection current and voltage has been obtained, the number of series and parallel connection of the thermoelectric generator can be calculated using equation (7) and (8). The current and voltage of each thermoelectric generator is taken from the highest mean value from the experiment, which is $0.34 \mathrm{~A}$ and $4.43 \mathrm{~V}$.

$N_{\text {TGs }}=\frac{16.27}{4.43}$

$N_{\text {TGs }}=4$

$N_{T G p}=\frac{2.66}{0.34}$

$N_{\text {TGp }}=8$

Then it can be concluded that the required thermoelectric generator to supply ICCP system is four series connections and eight parallel connections, resulting 32 total number of thermoelectric generator.

The thermoelectric generator will be placed in the engine room as shown in Figure 4. Specifically, it will be placed on exhaust gas pipe from the main engine as shown in Figure 5. 
International Journal of Marine Engineering Innovation and Research, Vol. 1(3), Jun. 2017. 143-148 (pISSN: 2541-5972, eISSN: 2548-1479)

TABLE 1.

EXPERIMENT RESULTS OF A THERMOELECTRIC GENERATOR

\begin{tabular}{ccccccc}
\hline No. & $\begin{array}{c}\text { Distance } \\
(\mathrm{m})\end{array}$ & Debit $(\mathrm{l} / \mathrm{min})$ & $\begin{array}{c}\mathrm{T}_{\text {hot }} \\
\left({ }^{\circ} \mathrm{C}\right)\end{array}$ & $\begin{array}{c}\mathrm{T}_{\text {cold }} \\
\left({ }^{\circ} \mathrm{C}\right)\end{array}$ & $\begin{array}{c}\text { Voltage } \\
(\mathrm{V})\end{array}$ & $\begin{array}{c}\text { Current } \\
(\mathrm{A})\end{array}$ \\
\hline 1 & 0.2 & 240 & 72 & 30 & 1.36 & 0.13 \\
\hline 2 & 0.2 & 420 & 112 & 31 & 2.15 & 0.19 \\
\hline 3 & 0.15 & 240 & 98 & 31 & 1.74 & 0.18 \\
\hline 5 & 0.15 & 420 & 129 & 31 & 2.83 & 0.24 \\
\hline 5 & 0.1 & 240 & 107 & 30 & 2.16 & 0.19 \\
\hline 7 & 0.1 & 420 & 156 & 32 & 3.72 & 0.3 \\
\hline 8 & 0.05 & 240 & 132 & 32 & 2.67 & 0.23 \\
\hline & 0.05 & 420 & 183 & 35 & 4.43 & 0.34 \\
\hline
\end{tabular}

TABLE 2.

PRINCIPLE DIMENSION OF LIVE FISH CARRIER "WELLbOAT"

\begin{tabular}{ccc} 
Parameter & Value & Unit \\
\hline $\mathrm{L}_{\mathrm{pp}}$ & 30.6 & $\mathrm{~m}$ \\
\hline $\mathrm{L}_{\mathrm{wl}}$ & 32.8 & $\mathrm{~m}$ \\
\hline Breadth & 7.5 & $\mathrm{~m}$ \\
\hline Depth & 5.7 & $\mathrm{~m}$ \\
\hline Draught & 4.2 & $\mathrm{~m}$ \\
\hline Wetted Area & 396.08 & $\mathrm{~m}^{2}$ \\
\hline Speed & 14 & Knot
\end{tabular}

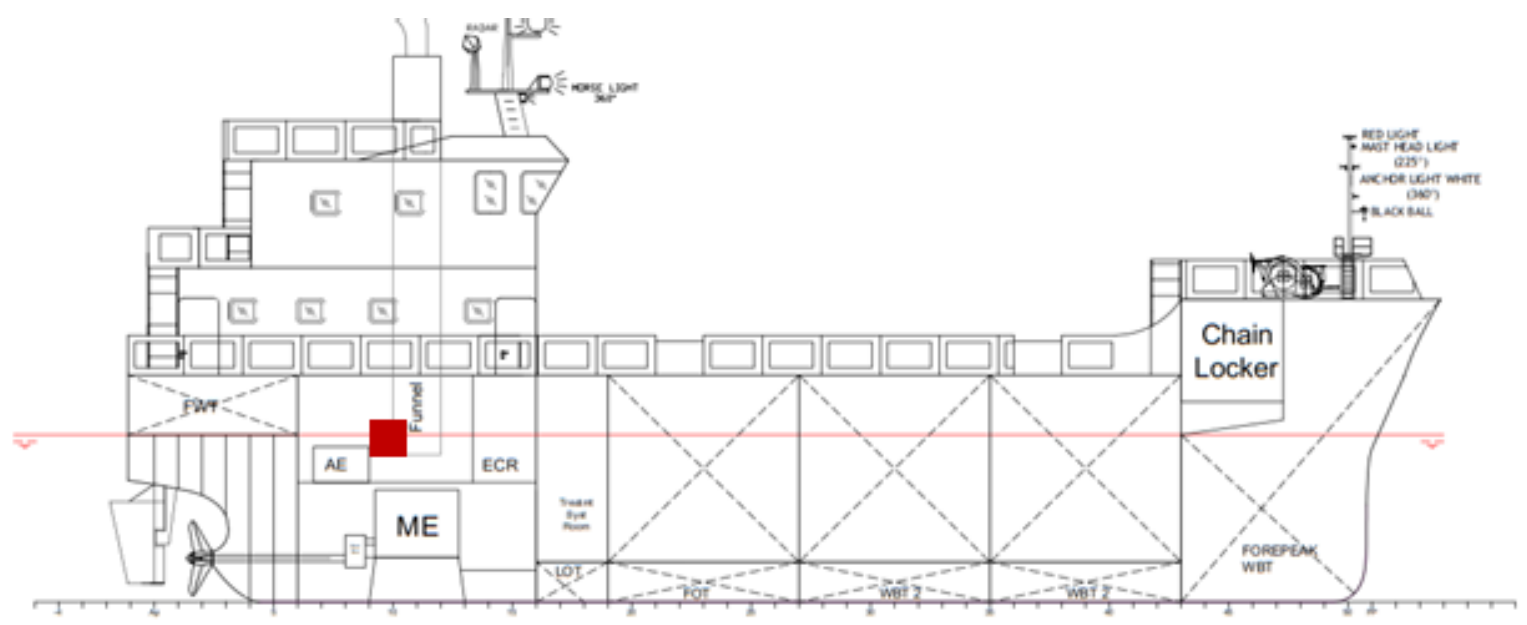

Figure. 4. Placement of Thermoelectric Generator in the "Wellboat" Ship 


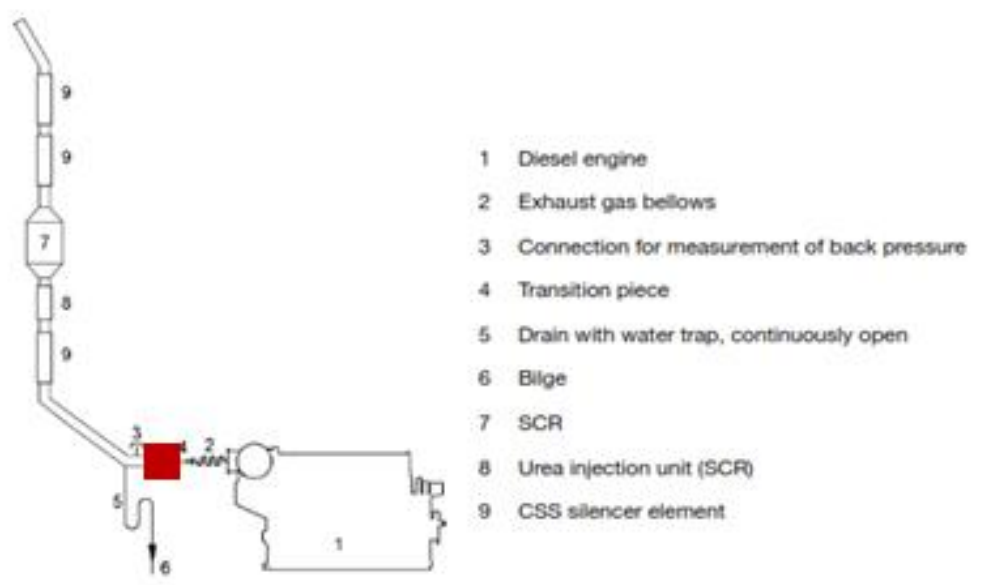

Figure. 5. Placement of Thermoelectric Generator on the Engine

\section{CONCLUSION}

This paper proposes a new method to protect the ship hull from the corrosion. The approach is using a waste energy in the form of exhaust gases from the ship main engine which is converted into electrical energy using thermoelectric generator. The prototype of the thermoelectric generator built in the experiment can generate mean value of $4.43 \mathrm{~V}$ voltages and $0.34 \mathrm{~A}$ current. To protect the $30 \mathrm{~m}$ ship, the number of required thermoelectric generator is only 32 . Since the production cost of a thermoelectric generator is only about 30 US Dollar, the total cost to protect the ship from the corrosion is relatively cheap.

\section{ACKNOWLEDGEMENTS}

This research is funded by the local fund of Institut Teknologi Sepuluh Nopember Surabaya, granted as part of the young researcher program awarded to Mr. Adi Kurniawan.

\section{REFERENCES}

[1] A. Wiludin, "Analisa Teknis dan Ekonomis Penggunaan ICCP (Impress Current Cathodic Protection) Dibandingkan dengan Sacrificial Anode dalam Proses Pencegahan Korosi," Bachelor Thesis Report in Institut Teknologi Sepuluh Nopember: Surabaya, 2013

[2] W.V. Beckmann, "Handbook of Cathodic Corrosion Protection 3rd Edition," Gulf Professional Publishing: Houston, 1997.

[3] A. Kurniawan, "A. Design of Neuro-Fuzzy Based Maximum Power Point Tracking on Photovoltaic System for Ship Lighting System," presented at the $3^{\text {rd }}$ International Symposium of Maritime Sciences, Kobe, Japan, 2014.

[4] A. Kurniawan, E. Haryanto, and A.A. Masroeri, "A neural network based maximum power point tracker with KY converter for photovoltaic system on a moving vehicle," presented at the $1^{\text {st }}$ International Conference on Advanced Mechatronics, Intelligent Manufacture, and Industrial Automation, Surabaya, Indonesia, 2015.

[5] E. Haryanto, A.A. Masroeri, and A. Kurniawan, "Optimasi Boost Converter Panel Surya sebagai Sumber Energi Alternatif Penerangan Kmp Allu. Dengan Metode Logika Fuzzy," Jurnal Teknik ITS,.vol.4 no.2, pp. B124-B129, October 2015.
[6] A. Kurniawan, "A Review of Solar-Powered Boat Development," IPTEK, the Journal for Technology and Science, vol. 27 no.1, pp. 1-8, April 2016

[7] A. Kurniawan, A.A. Masroeri, and E.S. Koenhardono, "NeuroFuzzy Based Maximum Power Point Tracker for Photovoltaic System on A Moving Vehicle," IPASJ International Journal of Computer Science, vo. 4 no. 10, pp. 1-9, October 2016.

[8] A. Kurniawan, E.S. Koenhardono, A.A. Masroeri, S. Sarwito, and A. Santoso, "Optimizing Solar-Powered Tourist Boat with Converter-Based Maximum Power Point Tracker,” . International Journal of Applied Engineering Research, vol. 11 no. 23, pp. 11142-11144, December 2016.

[9] I. Fauzi, A. Firdaus, I.R. Kusuma, and Z. Nasrullah, "Analysis of Batechsant (Battery Technology of Sound Power Plant): The Degree of Micro-vibration and Reverberation in Ship Engine Rooms," presented at the National Association of African American Studies, USA, 2013.

[10] A. Kurniawan, F. Adam, S.P. Fitri, and S. Sarwito, "Experimenta Study of Magnesium Anode Voltaic Cell as Electrical Source of Impressed Current Cathodic Protection for Ship Hull,' International Journal of Applied Engineering Research, vol. 11 no. 24, pp. 11647-11650, December 2016.

[11] G.J. Snyder, "Small Thermoelectric Generator," Electrochemica Society Interface, vol. 17, no. 3, pp. 54-56, 2008 